Portland State University

PDXScholar

Engineering and Technology Management

Faculty Publications and Presentations

\title{
Benchmarking and Evaluating the Efficiency of Mass Transit Systems Based on Best Practice Using Data Envelopment Analysis
}

\author{
Jacqueline Nayame \\ Portland Bureau of Transportation \\ Maoloud Dabab \\ Portland State University \\ Timothy Anderson \\ Portland State University
}

Follow this and additional works at: https://pdxscholar.library.pdx.edu/etm_fac

Part of the Automotive Engineering Commons

Let us know how access to this document benefits you.

\section{Citation Details}

J. Nayame, M. Dabab and T. Anderson, "Benchmarking and Evaluating the Efficiency of Mass Transit Systems Based on Best Practice Using Data Envelopment Analysis," 2019 Portland International Conference on Management of Engineering and Technology (PICMET), Portland, OR, USA, 2019, pp. 1-8.

This Article is brought to you for free and open access. It has been accepted for inclusion in Engineering and Technology Management Faculty Publications and Presentations by an authorized administrator of PDXScholar. Please contact us if we can make this document more accessible: pdxscholar@pdx.edu. 


\title{
Benchmarking and Evaluating the Efficiency of Mass Transit Systems Based on Best Practice Using Data Envelopment Analysis
}

\author{
Jacqueline Nayame $^{1}$, Maoloud Dabab ${ }^{2}$, Timothy Anderson ${ }^{2}$ \\ ${ }^{1}$ Portland Bureau of Transportation, City of Portland, Portland, OR - USA \\ ${ }^{2}$ Dept. of Engineering and Technology Management, Portland State University, Portland, OR - USA
}

\begin{abstract}
Public transit systems in the USA have been faced with mounting pressure to decrease their operating costs while at the same time expected to increase ridership and meeting multiple societal needs. The primary objective of this study is to measure the efficiencies of mass transit agencies based on best practice in the US, identify the influencing factors leading to their efficiencies, and how these strategies and policies can be used improve inefficiency in transit agencies. Using Data Envelopment Analysis (DEA) method, the study analyzed the mass performance of 334 transit agencies across the US using data from the national transit database (NTD) for the five years (2012 to 2016). The results show that public transit agencies operating ridesharing programs such as vanpools and on demand-services are more efficient compared to other agencies, as they are able to better at utilizing their inputs and therefore having a higher overall efficiency.
\end{abstract}

\section{INTRODUCTION}

Public transit systems in the USA have been faced with mounting pressure to decrease their operating costs while at the same time expected to increase ridership and meeting multiple societal needs (such as providing paratransit services or reducing congestion). Operating a transit agency under a restricted budget and trying to meet the expanding societal needs puts much pressure on the managers of these transit agencies. One alternative to tackling the decrease in funding is to increase transit fares and decrease service offered [23]. However, such a policy would only disadvantage the very population that the public transit is supposed to be helping such as the unemployed and those who depend on transit to get to their destinations [3]. The impact of declining revenues can be lessened by improving the performance and efficiency of public transportation systems. If public transport is not efficient, it becomes less desirable and leads to more people opting to drive instead of using it. This would then defeat one of the primary objectives of reducing $\mathrm{CO} 2$ emissions by providing sustainable transportation and reducing driving.

Comparing an individual transit system's effectiveness with those of its peers especially in translating its operating costs into actual transit service is important to different stakeholders [18]. Therefore, improving the management of these public transit agencies is an important issue. It is important to define the best way to measure the performance and efficiency of public transit. This study aims to measure the efficiency of mass transit in the US. This study is a follow up to Min and Ahn's research [15] on 'Benchmarking Mass transit Systems in the USA.' They looked at data investigated mass transit efficiency by focusing on data from 2007 to 2011, while the current research focuses on the data from 2012 to 2016 and we also add one more output "unlinked passenger trips."

The structure of this paper is as follows. Section 2 discusses various concepts and status the prior work on transportation using DEA. Section 3 provides the principal details of the proposed methodology and concept of the models. Data and the inputs versus the outputs status of variables are explored in Section 4. Section 5, reviews the results and discusses the efficiency analysis of the transit centers. Concluding remarks follow in Section 6.

\section{LITERATURE REVIEW}

\section{A. Public transportation}

Public transportation systems include a variety of transit types such as Bus, Tram, Taxi, Metro, Train, and so on. At the same time, there are many transportation systems including urban transport, regional transport, and rail transport. Public transportation offers a number of benefits that may include; (1) reduction in traffic congestion, (2) improves mobility and accessibility to a variety of destinations, (3) improves mode choice as it offers a number of different modes choice alternatives, (4) reduce annual household vehicle miles traveled, (5) reduces carbon emissions and (6) leads to economic and community growth by providing individuals access to jobs [14] [15] [24]. Based on a review of literature on the economic benefits of public investment in transportation, Bhatta and Drennan identified a number of long-term economic benefits of public investments in public transportation such as increase in income, higher property values, increase in employment and real wages, and reductions in noncommercial travel time, improved access and improved quality of life [4]. While public transit helps maintain the vitality of our major cities and all segments of society, it is a critical part of lowincome people. Glaeser, Kahn, and Rappaport established the role of mass transit and public transportation and how they provide the facilities in daily life to poor people [21]. 
The rise of Transportation Network Company (TNCs) such as Uber and Lyft have also affected transit ridership. Research has shown that TNCs can be a compliment transit service or led to a reduction in transit usage depending on the type of transit service in question. According to Babar and Burtch [30], the entry of ride-hailing services has led to a significant reduction in the utilization of road-based public transit services, while increasing utilization of rail-based and long-haul transit services such as subway and rail. In 2017, a study by Clewlow and Mishra found an overall 6\% reduction in transit usage across major American cities due to the use of Uber and Lyft [31]. The research also found that $49 \%$ to $61 \%$ of ride-hailing trips "would not have been made at all, or made by walking, biking, or transit."

\section{B. Performance of Public Transit Systems}

Evaluating the performance of public transit is significant for making suitable improvements in the public transport system. Due to a lack of a specific guide to measuring the performance of public transit systems, studies have focused on various quantitative measures to be used for evaluating the degree to which these organizations can meet their objectives. A study by Tomazinis [19] identified a set of indicators to measure the performance of public transportation systems and focused on the conceptual analysis of this evaluation on; productivity, efficiency and quality of service. Efficiency indicators are used to measure the extent to which the resources are used economically.

On the other hand, effectiveness measures how well services produced to meet the set objectiveness [18]. Economists have traditionally distinguished efficiencies from two different perspectives technical efficiency and allocative efficiency [7] [11]. Technical efficiency is the degree to which transit agencies can achieve maximum possible outputs (vehicle miles traveled) with given inputs (fuel, fares, labor). A transit agency is technically inefficient if production occurs in the interior of its production possibility set. Allocative efficiency is defined by a point on the boundary of the possibility set that satisfies the objective given certain constraints on prices and quantities [6]. The performance assessment and evaluation of public transit systems can help transit agencies to identify underperforming services and improve their performance [22]. There are many tools to analyze the efficiency of the transit system overall and individual transit center comparing with best practices in the system. In this study, we use one of the widely used methods, which is DEA, to measuring the performance of transit.

\section{Early work of DEA Application in Transportation}

One of the earliest attempts of using DEA to analyze transit performance is a study by Kusbiantoro in 1985 [25]. Since these were not truly compatible, this study violated one of the critical requirements of using DEA, which assumes that the systems are similar, and the inputs and outputs are identical. The DEA methodology can be used to determine the relative efficiency of each member of a set of comparable transit agencies by computing a ratio of weighted resource input values to weighted service output values for each of the transit agencies [18].

DEA assigns a score of less than one to inefficient DMUs and a score of 1 to efficient units. No assumption about the valuable distance or the production frontiers form is needed to measure efficiency because the frontier is the observed 'best practice' in the data set available. The frontier methodology enables us to be able to distinguish between efficient and inefficient transit agencies and to be able to determine the degree of inefficiency by using the best practice standard industry as a benchmark [6]. For example, if transit agency A is able to produce $\mathrm{Y}(\mathrm{A})$ outputs with $\mathrm{X}(\mathrm{A})$, then the other transit agencies within the same group to do the same if they are operating efficiently. DEA allows the efficiency of one transit agency to be measured relative to the other agencies in the group. It allows the managers of transit managers to be able to detect whether an increase in outputs or decrease in outputs would lead to these agencies to improve their relative efficiency. Due to its capabilities of being able to recognize inefficient DMUs from the efficient DMUs within the same group, it can be considered a useful tool for developing mass transit benchmarking standards [14] [15]. According to [9], narrowing the range of agency size is important when analyzing transit agency performance because smaller and larger transit agencies are less efficient compared to intermediate agencies.

Viton in [20] used DEA to examine the efficiency of a transit system relative to the other agencies within the same peer group using US bus transit data between 1988 and 1992. Their results showed that productivity improved slightly and technical inefficient declined over the observed period. A study by [9] on the hand proposed the use of DEA to develop a single measure relative efficiency and single measure effectiveness of a transit agency compared to other agencies within the same peer group.

Nolan proposed using DEA to measure the relative operating efficiencies of 25 selected transit agencies in the USA [16]. They found that among the controllable factors considered, average fleet age to be negatively correlated with the transit efficiency and they also found that federal operating subsidies to have negative impacts on efficiency. However, locally based subsidies were found to have a positive effect on transit efficiency.

A study by Fu, Yang, and Casello evaluated the efficiency levels of individual paratransit systems using 32 paratransit agencies in Canada with the specific objective of identifying the most efficient agencies and the source of their efficiencies using DEA [10]. However, identification of the most efficient systems along with the key influencing factors, they developed new service policies, management, and operational strategies that would be used for improving resource utilization and quality of service. Sulek and Lind in [18] proposed a systematic approach to measuring transit performance that integrates the issues of service quality, efficiency, and effectiveness.

Using data collected from surveys of paratransit riders in the Toledo metropolitan areas, Min investigated the effectiveness 
of paratransit services and identified the key factors influencing paratransit service quality (such as door-to-door or curb-tocurb services, flexible pick-up/drop-off windows, handling of late-cancellations and no-shows, shared-rides, short-notice services, peak hour feeder services, and overnight service that influence the overall service quality of paratransit in the Toledo metropolitan area [13]. Additionally, He discovered that a private contractor hired was effectively succeed in controlling the operating costs. However, this leads to deteriorating in the service quality of the paratransit services. The results also showed that the paratransit services improved once paratransit services were no longer outsourced but operated in-house.

Shioda, Shea, and $\mathrm{Fu}$ proposed a tool that would compute performance metrics reflecting the key interests of paratransit stakeholders such as drivers, passengers, and so on [17]. The computerized tool also included a data-mining tool to fit the metrics ratings provided by experienced schedulers. These performance metrics include a number of passengers per vehicle per hour, deadheading time, passenger wait time, passenger ride time. The results from the tool showed it could be used improving the overall efficiency of paratransit service quality and extended to other different paratransit organizations.

Boame proposed the use of bootstrap DEA method and Tobit regression to estimate the technical efficiency scores for the Canadian urban transit systems from 1990 to 1998 [5]. As expected, the results show that while higher average transit speed increases efficiency peaking decreases efficiency.

\section{METHODOLOGY}

\section{A. Data Envelopment Analysis (DEA)}

DEA was first proposed in 1978 [8]. DEA is used to determine the relative efficiency of a set of producers (decisionmaking units or DMUS) and to evaluate the performance of these organizations. The relative efficiency of each DMU is defined in a nonlinear programming model. In 1993, Andersen and Petersen introduced super efficiency as a ranking methodology for differentiating efficient DMUs [1]. The main objective of this approach is the ability to discriminate between efficient DMUs, which helps the scholars to measure the efficiency and distinguish economically viable units from units that are only technically efficient and ranking the efficient DMUS based on parametric methods. The efficient procedure ranks efficient DMUs by comparing the unit under evaluation with a linear combination of all the other units in the sample with that DMU excluded from the sample.

\section{B. CCR Model}

The CCR model was developed by Charnes, Cooper, and Rhodes [8]. The objective of the model is to maximize the ratio of weighted outputs to weighted inputs. The CCR model considers a constant return to scale (CRS). Below is the mathematical expression for the CCR model [8].

$$
\operatorname{Maxh}_{0}=\frac{\sum_{r=1}^{s} u_{r} y_{r 0}}{\sum_{i=1}^{m} v_{i} x_{i 0}}
$$

Subject to:

$$
\begin{aligned}
& \frac{\sum_{r=1}^{s} u_{r} y_{r j}}{\sum_{i=1}^{m} v_{i} x_{i j}} \leq 1 ; j=1 \ldots . n \\
& u_{r}, v_{i} \geq \mathcal{E} ; r=1 \ldots . . s, \quad i=1 \ldots m
\end{aligned}
$$

Whereas $y_{r i} y_{r i}$ is the known amount of r produced by DMU $\mathrm{j}, x_{i j} x_{i j}$ is the known amount of input I used by DMU j, $u_{r} u_{r}$ is the weight given to output $\mathrm{r}, v_{i} v_{i}$ is the weight given to input $\mathrm{I}$, $\mathrm{n}=$ to the number of DMUS, $\mathrm{s}=$ the number of outputs and $\mathrm{m}$ $=$ the number of inputs.

\section{BCC Model}

Banker, Charnes, and Cooper in 1984 proposed BCC model which is an extension to the CCR model [2]. The BCC model considers variable returns to scale (VRS). The model allows the production frontier to move away from the origin by introducing a constant in aggregating either the inputs or the outputs.

$$
\operatorname{Max} Z_{0}=\sum_{r=1}^{t} u_{r} y_{r 0}-w
$$

Subject to:

$$
\sum_{i=1}^{m} v_{i} x_{i 0}=1
$$

$\sum_{r=1}^{\mathrm{t}} u_{r} y_{i j}-\sum_{i=1}^{m} v_{\mathrm{i}} x_{i j}-w \leq 0, \quad j, \ldots \ldots, n$

$u_{r}, v_{i} \geq \mathcal{E}, \quad r, \ldots \ldots, t, \quad i=1, \ldots \ldots, m$

$\mathrm{W}=$ free (unconstrained in sign)

\section{BuILding THE MOdeL}

\section{A. Inputs and Outputs Specifications}

In our study of transit agencies, an efficiency score implies a transit agency's ability to efficiently transform a set of three inputs (use of minimum resources) into a set of three outputs as follows: 


\section{a) INPUTS}

- Labor hours - is the total number of part-time and full-time employees invested in the operation of the mass transit system and indicates how well these human resources are utilized. This includes operators, maintenance, and administrative personnel. The labor costs comprise about $75 \%$ of the total cost of operating public transit systems. Therefore, they are a critical component in evaluating their performance [18].

- Service Area Density Population - research shows that densely populated areas are more likely to use public transit compared to less densely populated areas [26]. This input represents the potential revenue from passengers.

- Total Operating Expenses - These are expenses associated with the operating of the transit agency. They include driver payroll, employee benefits, pension contributions, utilities, general administration expenditures, and vehicle repair and maintenance costs [27].

\section{b) OUTPuTs}

- Total Revenue Vehicle Miles - defined as total miles traveled while in revenue generating service. Revenue vehicle miles is frequently used as a measure of the efficiency of the mass transit system as it avoids those vehicle mileages that are unproductive and should, therefore, be counted as contributing to the system efficiency (e.g., deadhead miles, road tests) [10] [15].

- $\quad$ Fare Revenue Earned - Fees collected from fares are an important part of a transit system's revenue stream, therefore are considered as an output [28]. This includes fares collected directly from carrying passengers or collected through, particular transit, passes, tickets, and so on.

- Unlinked Passenger Trips - This measures the number of times passengers board public transit. Passengers are counted each time they board they board a vehicle even if the boarding is part of the same journey from origin to destination regards of the type of fare paid or transfer presented. This measure represents how passengers use frequent transit vehicles. The more frequently passengers use the transit vehicle the less likely it will fail to meet its capacity and therefore the less likely it is to make empty trips [29]. This input can be used to measure vehicle utilization ratio.

\section{B. Data for the model}

In order to measure the efficiency of mass transit in the US, we used both the CCR model and the BCC model. Data used in our model is data of 335 US mass transit agencies collected from the national transit database. Table I shows descriptive statistics for out inputs and outputs, which indicates that, there is a range of transit agencies with different sizes. The data is a public data, and to access to the data check this website (https://www.transit.dot.gov/ntd).

\section{RESUlTS AND ANALYSIS}

The results in Table II shows the top 17 efficient transit agencies. Super efficiency was used as a tool to rank efficient DMUs. One of the major concerns of using super-efficiency is the issue of infeasibility. Infeasibility in super-efficiency models occurs when an efficient DMU under evaluation is not operating near the frontier formed by its production set through an increase in the inputs or a decrease in outputs [12].

As can be noted from Table II, the first four transit agencies; Charlotte County Transit Division, the Transportation Management Association Group, Brunswick Transit Alternative, Coralville Transit Systems were found to have no infeasible solution for super-efficiency. This might be due to these DMUs not being close to the frontier formed by the rest of the DMUs in this production set due to a variety of reasons. To elaborate further on the likely causes for the infeasible solutions a profile of each of the agencies is provided. Charlotte County Transit Division provides curb-by-curb transit service for residents needing transportation to and from their destinations in Charlotte County including Punta Gorda, Port Charlotte, and Eaglewood.

TABLE I. DEsCRIPTIVE STATISTICS

\begin{tabular}{|c|c|c|c|c|c|c|}
\hline & \multicolumn{3}{|c|}{ Inputs } & \multicolumn{3}{c|}{ Outputs } \\
\hline & $\begin{array}{c}\text { Service Area } \\
\text { Population }\end{array}$ & $\begin{array}{c}\text { Total Operating } \\
\text { Hours }\end{array}$ & $\begin{array}{c}\text { Total Operating } \\
\text { Expenses }\end{array}$ & Revenue Fares & $\begin{array}{c}\text { Annual Vehicle } \\
\text { Revenue Miles }\end{array}$ & Unlinked Passenger Trips \\
\hline Max & $18,351,295$ & $93,716,511$ & $9,148,851,698$ & $4,330,281,843$ & $536,154,856$ & $3,464,743,546$ \\
\hline Min & 5,443 & 1,040 & 256,038 & 950.00 & 4.07 & 22.39 \\
\hline Mean & 975,433 & $1,422,983$ & $111,146,400$ & $41,133,330$ & $3,712,438$ & $11,385,355$ \\
\hline SD & $2,015,217$ & $5,656,340$ & $505,089,381$ & $244,583,831$ & $22,443,342$ & $125,124,792$ \\
\hline
\end{tabular}


TABLE II. OVERALL EFFICIENCY SCORES OF MASS TRANSIT SYSTEMS

\begin{tabular}{|c|c|c|c|c|c|c|c|c|c|c|}
\hline & \multirow{2}{*}{ Agency Name } & \multirow{2}{*}{ State } & \multicolumn{2}{|c|}{$\begin{array}{c}\text { Input- } \\
\text { Oriented }\end{array}$} & \multicolumn{2}{|c|}{$\begin{array}{c}\text { Super- } \\
\text { efficiency }\end{array}$} & \multicolumn{2}{|c|}{$\begin{array}{l}\text { Output- } \\
\text { Orientated }\end{array}$} & \multicolumn{2}{|c|}{$\begin{array}{c}\text { Super- } \\
\text { efficiency }\end{array}$} \\
\hline & & & CRS & VRS & CRS & $\begin{array}{l}\text { VRS } \\
\end{array}$ & CRS & VRS & CRS & VRS \\
\hline 1 & Charlotte County Transit Division & FL & 0.552 & 1 & 0.648 & 2.153 & 0.552 & 1 & 0.648 & Inf \\
\hline 2 & The Transportation Management Association Group & $\mathbf{T N}$ & 0.861 & 1 & 0.969 & 1.981 & 0.861 & 1 & 0.969 & Inf \\
\hline 3 & Brunswick Transit Alternative & OH & 0.223 & 1 & 0.223 & 2.025 & 0.223 & 1 & 0.223 & Inf \\
\hline 4 & Coralville Transit System & IA & 0.412 & 1 & 0.412 & 1.539 & 0.412 & 1 & 0.412 & Inf \\
\hline 5 & MTA New York City Transit & NY & 1 & 1 & 1.434 & Inf & 1 & 1 & 1.434 & 6.396 \\
\hline 6 & vRide, Inc. - Atlanta & GA & 1 & 1 & 2.192 & 2.631 & 1 & 1 & 2.192 & 2.908 \\
\hline 7 & University of Georgia Transit System & GA & 1 & 1 & 2.123 & 2.647 & 1 & 1 & 2.123 & 2.218 \\
\hline 8 & The University of Montana - ASUM Transportation & MT & 0.909 & 1 & 0.975 & 1.429 & 0.909 & 1 & 0.975 & 1.871 \\
\hline 9 & $\begin{array}{l}\text { VRide, Inc. - Michigan } \\
\end{array}$ & MI & 1 & 1 & 1.517 & 5.946 & 1 & 1 & 1.517 & 1.721 \\
\hline 10 & San Francisco Bay Area Rapid Transit District & $\mathbf{C A}$ & 1 & 1 & 1.518 & 1.698 & 1 & 1 & 1.518 & 1.643 \\
\hline 11 & Dallas - vRide, Inc. & TX & 1 & 1 & 1.339 & 1.452 & 1 & 1 & 1.339 & 1.559 \\
\hline 12 & North Front Range Metropolitan Planning Organization & $\mathrm{CO}$ & 0.911 & 1 & 1.106 & 1.416 & 0.911 & 1 & 1.106 & 1.379 \\
\hline 13 & Mountain Metropolitan Transit & $\mathrm{CO}$ & 0.990 & 1 & 1.271 & 2.135 & 0.990 & 1 & 1.271 & 1.325 \\
\hline 14 & vRide, Inc. - Denver & $\mathrm{CO}$ & 0.898 & 1 & 0.903 & 1.474 & 0.898 & 1 & 0.903 & 1.320 \\
\hline 15 & Port Imperial Ferry Corporation dba NY Waterway & NJ & 0.871 & 1 & 0.858 & 1.193 & 0.871 & 1 & 0.858 & 1.178 \\
\hline 16 & Trans-Bridge Lines, Inc. & PA & 0.880 & 1 & 0.907 & 1.087 & 0.880 & 1 & 0.907 & 1.083 \\
\hline 17 & Orange-Newark-Elizabeth, Inc. & NJ & 0.886 & 1 & 0.908 & 1.091 & 0.886 & 1 & 0.908 & 1.071 \\
\hline
\end{tabular}

They operate on an advanced reservation basis. This allows the agency to maximize their outputs. The Transportation Management Association Group customizes alternative transportation, money-saving solutions for employers and commuters in fourteen Tennessee counties. They provide interconnected transportation services by offering ridesharing programs, on-demand curb-to-curb services that allows for a seamless, coordinated multimodal transit system within the fourteen counties in the region. This leads to a reduction in low occupancy vehicles as more people chose to vanpool to commute to and from work.

The Brunswick Transit Alternative (BTA) is a transit agency serving the city of Brunswick, Ohio. It operates two fixed routes that circulate through the City of Brunswick at regularly scheduled. BTA merged with Medina County Public transit in 2017 (though the talks of a merger had been going on since 2015). MTA New York Transit is the busiest and most extensive transit system in North America; it has a daily ridership of 8 million trips. It makes sense that this transit system has an unusually high super efficiency of 6.396 because it is too large to be compared to the transit systems in this set, unless it was being compared to systems with similar size or ridership like the transit systems in London, Japan or China. Therefore, in trying to find the benchmarking of mass transit the first five transit systems should be removed from the production set for reasons mentioned above as they create an unfair disadvantage for the other agencies. The locations of these agencies on the frontier is too far to be comparable to the other transit systems in the set.
Therefore, in trying to find the best practices or standards for mass transit agencies, we should look at transit agencies ranked six onwards. In addition, in our top 17 efficient transit systems, we see some university-run transit systems. Ride, Inc. (Atlanta) operates as a vanpool and ridesharing platform. It provides a ride-matching system that links people with similar commutes; the company enables users to create pools, including vanpools and carpools. Its services include matching coworkers, arranging the rides, processing transactions, and creating monthly reports for its clients' savings and sustainability. University of Georgia Transit System operates on the University of Georgia campus and the immediate vicinity. All fixed routes are fare-free and open to anyone including students and the public. The system is funded mostly through a transportation fee charged to students per semester. Seeing that University of Georgia Transit System operates around the campus area, it means it always has a good ridership number as most students live around campus.

The bottom five inefficiency agencies are Puerto Rico Maritime Transport Authority, City of Glendale Transit, Huntington Area Rapid Transit, Delaware County Transit Board, and Johnson County SEATS. Puerto Rico Maritime Transport Authority is a government-owned transit agency that operates marine transportation services within Puerto Rico and the island municipalities of Vieques and Culebra. The city of Glendale Transit offers some transportation services to Glendale residents. We see that one of their sources of inefficiency is the decrease in fares from 2014 to 2016, yet we see an increase in vehicle revenue miles and unlinked passenger trips in 2015. Huntington Area Rapid Transit is a government- 
owned bus system that operates within the Town of Huntington, New York. It operates regularly scheduled, fixed-route buses as well as paratransit for seniors and people with disabilities. We see an increase in operating expenses from 2014 to 2016 . The operating expenses increased from $\$ 3,862,185$ to $\$ 4,131,045$ in 2014. The Delaware County Transit Board is a board appointed by Delaware County and is responsible for providing direction, governing the transit system through the development of policies for the system's operations and advancing the transit system in the community. Johnson County SEATS provides transportation services to senior citizens, people with disabilities to get to their destinations such as doctor's appointments, grocery shopping in Johnson County Iowa. One of the sources of efficiency is the increase in the transit system's increase in operating costs as well as in vehicle revenue miles.

One of the patterns that arise from looking at the inefficiency transit systems is that almost all of them only offer one type of mode. They do not provide multimodal transportation systems; there is no/poor connection to other types of modes. This leads to difficulties in transferring from one mode to another and there leads to a transfer penalty, which makes most people in these areas to opt to drive to avoid these inconveniences. We also notice that transit systems independent or privately operated tend to be more efficient compared to those that are government managed.

\section{CONCLUSION}

As can be noted above and looking at table II, we see that public transit systems operating ridesharing programs such as vanpools and on demand-services are more efficient compared to other systems, as they are able to utilize their inputs better and therefore having a higher overall efficiency. When analyzing mass transit in the US, it is essential to take in account the type of organization the transit system is (privately owned or publicly owned) as this has an impact on the efficiency priority. The size of the transit agency is important and the type of services they offer. For example, MTA New City Transit System provides a seamless connection between different modes, which makes it easy for users to make their transfers. Whereas, some agencies do not offer good transfer connection between modes which might deter people from using these public transit agencies.

We found that transit agencies such as Vride, Inc-Atlanta, California Vanpool Authority, offering vanpool and ridesharing services tend to perform better than those transit agencies relying on ferryboat operations. This tells us that the type of transportation mode offered influences whether the transit system is efficient or not. With more and more people, commuting and working further away from their homes, the vanpool and ridesharing programs are a key area for public transit agencies to invest in. Investing in these type of programs is cheaper than investing in other mass transit transportation such as rail or marine transportation, this is because the infrastructure is already there and the only thing required is to get the vanpools. Most research has concluded that privately operated transit agencies are more efficient than publicly operated ones because the main goal of privately operated agencies is to make a profit. Our results support the conclusion that privately operates agencies. Of the top 17 efficient transit agencies observed, 10 of those are privately operated agencies. However, it is worthwhile for managers of public operated transit agencies to look at the things that are making privately operated transit to be more efficient and see how they can emulate these policies.

Transit agency managers should examine the impact of Transportation Network Companies (TNCs) or ridesharing services such as Uber and Lyft on transit ridership. Research has shown that TNCs can be a compliment transit service or led to a reduction in transit usage depending on the type of transit service in question. According to Babar and Burtch [30], the entry of ride-hailing services has led to a significant reduction in the utilization of road-based public transit services, while increasing utilization of rail-based and long haul transit services such as subway and rail. A study by Clewlow and Mishra [31] found an overall $6 \%$ reduction in transit usage across major American cities due to the use of Uber and Lyft. The research also found that $49 \%$ to $61 \%$ of ride-hailing trips "would not have been made at all, or made by walking, biking, or transit." Transit agencies maybe should see the emergence of ridesharing services as a strategic opportunity and not a threat, and consider how they can collaborate and use these services to improve increase ridership.

Finally, in future work, we should explore how size and type of DMU affect the efficiency ranking by dividing the DMUs into two groups according to size and type. We would also like to explore what type of partnership between transit agencies and ridesharing services would lead to transit agencies being more efficient.

\section{REFERENCES}

[1] P. Andersen and N. C. Petersen, "A Procedure for Ranking Efficient Units in Data Envelopment Analysis," Management Science, vol. 39, no. 10, pp. 1261-1264, 1993.

[2] R. D. Banker, A. Charnes, and W. W. Cooper, "Some Models for Estimating Technical and Scale Inefficiencies in Data Envelopment Analysis," Management Science, vol. 30, no. 9, pp. 1078-1092, 1984.

[3] D. T. Barnum, M. G. Karlaftis, and S. Tandon, "Improving the efficiency of metropolitan area transit by joint analysis of its multiple providers," Transportation Research Part E: Logistics and Transportation Review, vol. 47, no. 6, pp. 1160-1176, 2011.

[4] S. D. Bhatta and M. P. Drennan, "The Economic Benefits of Public Investment in Transportation," Journal of Planning Education and Research, vol. 22, no. 3, pp. 288-296, 2003.

[5] A. K. Boame, "The technical efficiency of Canadian urban transit systems," Transportation Research Part E: Logistics and Transportation Review, vol. 40, no. 5, pp. 401-416, 2004.

[6] B. D. Borger, K. Kerstens, and Á. Costa, "Public transit performance: What does one learn from frontier studies," Transport Reviews, vol. 22, no. 1, pp. 1-38, 2002.

[7] M. Brons, N. Peter, P. Eric, and R. Piet, "Efficiency of Urban Public Transit: A meta-Analysis." Transportation vol. 32, no. 1 pp.1-21, 2005.

[8] A. Charnes, W. Cooper, and E. Rhodes, "Measuring the efficiency of decision-making units," European Journal of Operational Research, vol. 2, no. 6, pp. 429-444, 1978.

[9] X. Chu, J. G. Fielding, and W. B. Lamar, "Measuring transit performance using Data Envelopment Analysis," Transportation Research Part A: Policy and Practice, vol. 26, no. 3, pp. 223-230, 1990. 
[10] L. Fu, J. Yang, and J. Casello, "Quantifying Technical Efficiency of Paratransit Systems by Data Envelopment Analysis Method," Transportation Research Record: Journal of the Transportation Research Board, vol. 2034, no. 1, pp. 115-122, 2007.

[11] M. G. Karlaftis and D. Tsamboulas, "Efficiency measurement in public transport: Are findings specification sensitive?" Transportation Research Part A: Policy and Practice, vol. 46, no. 2, pp. 392-402, 2012.

[12] M. Mehdiloozad, and R. Israfil, "Analyzing the concept of superefficiency in data envelopment analysis: A directional distance function approach," arXiv preprint arXiv: 1407.2599, 2014

[13] H. Min, "Evaluating the service quality of para-transit systems: an exploratory study of the Toledo area regional transit authority," International Journal of Logistics Systems and Management, vol. 9, no. 3, p. 315, 2011.

[14] H. Min, "Assessing the Efficiency of Mass Transit Systems in the United States," 2017.

[15] H. Min and Y.-H. Ahn, "Dynamic Benchmarking of Mass Transit Systems in the United States Using Data Envelopment Analysis and the Malmquist Productivity Index," Journal of Business Logistics, vol. 38, no. 1, pp. 5573, 2017.

[16] J. Nolan, P. Ritchie, and J. Rowcroft, "Identifying and measuring public policy goals: ISTEA and the US bus transit industry," Journal of Economic Behavior \& Organization, vol. 48, no. 3, pp. 291-304, 2002.

[17] R. Shioda, M. Shea, and L. Fu, "Performance Metrics and Data Mining for Assessing Schedule Qualities in Paratransit," Transportation Research Record: Journal of the Transportation Research Board, vol. 2072, no. 1, pp. 139-147, 2008.

[18] J. M. Sulek, and M. R. Lind, "A Systems Model for Evaluating Transit Performance," Journal of Public Transportation, vol. 3, no. 1, pp. 29-47, 2000.

[19] A. R. Tomazinis, "A Study of Efficiency Indicators of under Public Transportation Systems," Final report. No. DOT-TST-77-47, Transportation Studies Center, 1977.

[20] P. A. Viton, "Changes in multi-mode bus transit efficiency, 1988 - 1992," Transportation 25, n. 1, pp. 1-21, 1998.
[21] E. L. Glaeser, M. E. Kahn, and J. Rappaport, "Why do the poor live in cities? The role of public transportation," Journal of Urban Economics, vol 63, no.1, pp. 1-24, 2008.

[22] R. Wei, X. Liu, Y. Mu, L. Wang, A. Golub, and S. Farber, "Evaluating public transit services for operational efficiency and access equity," Journal of Transport Geography, vol. 65, pp. 70-79, 2017.

[23] Z. She, D. M. King, and S. H. Jacobson, "Is promoting public transit an effective intervention for obesity?" Transportation Research Part A: Policy and Practice, vol. 119, pp. 162-169, 2019.

[24] K. Martens, A. Golub, and G. Robinson, "A justice-theoretic approach to the distribution of transportation benefits: Implications for transportation planning practice in the United States," Transportation Research Part A: Policy and Practice, vol. 46, no. 4, pp. 684-695, 2012.

[25] X. Kusbiantoro. "A Study of Urban Mass Transit Performances: Concept, Measurement, and Explanation." Ph.D. diss., Graduate School of Arts and Sciences, University of Pennsylvania, 1985.

[26] R. Ewing, R. Pendall, and D. Chen, "Measuring Sprawl and Its Transportation Impacts," Transportation Research Record: Journal of the Transportation Research Board, vol. 1831, no. 1, pp. 175-183, 2003.

[27] M. G. Karlaftis and P. Mccarthy, "Cost structures of public transit systems: a panel data analysis," Transportation Research Part E: Logistics and Transportation Review, vol. 38, no. 1, pp. 1-18, 2002.

[28] M.-P. Pelletier, M. Trépanier, and C. Morency, "Smart card data use in public transit: A literature review," Transportation Research Part C: Emerging Technologies, vol. 19, no. 4, pp. 557-568, 2011.

[29] J. Pucher, "Renaissance of public transport in the United States," Transportation Quarterly vol. 56, no. 1, pp. 33-49, 2002.

[30] Y. Babar, and G. Burtch, "Examining the Impact of Ridehailing Services on Public Transit Use," SSRN Electronic Journal. 10.2139/ssrn.3042805, 2017.

[31] R. R. Clewlow and S. M. Gouri, "Disruptive transportation: the adoption, utilization, and impacts of ride-hailing in the United States." University of California, Davis, Institute of Transportation Studies, Davis, CA, Research Report UCD-ITS-RR-17-07 (2017).

APPENDIX

OVERALL TRANSIT EFFICIENCY

\begin{tabular}{|c|c|c|c|c|c|c|c|c|c|c|}
\hline & \multirow[t]{2}{*}{ Agency Name } & \multirow[b]{2}{*}{ State } & \multicolumn{2}{|c|}{$\begin{array}{c}\text { Input- } \\
\text { Oriented } \\
\text { Efficiency }\end{array}$} & \multicolumn{2}{|c|}{$\begin{array}{l}\text { Output- } \\
\text { Oriented } \\
\text { Efficiency }\end{array}$} & \multicolumn{2}{|c|}{$\begin{array}{l}\text { Input- } \\
\text { Oriented } \\
\text { Super } \\
\text { Efficiency }\end{array}$} & \multicolumn{2}{|c|}{$\begin{array}{l}\text { Output- } \\
\text { Oriented } \\
\text { Super } \\
\text { Efficiency }\end{array}$} \\
\hline & & & CCR & BCC & CCR & BCC & CCR & BCC & CCR & BCC \\
\hline 1 & Charlotte County Transit Division & FL & 0.552 & 1 & 0.552 & 1 & 0.648 & 2.152 & 0.648 & Inf \\
\hline 2 & The Transportation Management Association Group & TN & 0.860 & 1 & 0.860 & 1 & 0.968 & 1.980 & 0.968 & Inf \\
\hline 3 & Brunswick Transit Alternative & $\mathrm{OH}$ & 0.222 & 1 & 0.222 & 1 & 0.222 & 2.024 & 0.222 & Inf \\
\hline 4 & Coralville Transit System & IA & 0.411 & 1 & 0.411 & 1 & 0.411 & 1.539 & 0.411 & Inf \\
\hline 5 & MTA New York City Transit & NY & 1 & 1 & 1 & 1 & 1.434 & Inf & 1.434 & 6.396 \\
\hline 6 & Ride, Inc. - Atlanta & GA & 1 & 1 & 1 & 1 & 2.191 & 2.631 & 2.191 & 2.907 \\
\hline 7 & California Vanpool Authority & $\mathrm{CA}$ & 0.857 & 0.950 & 0.857 & 0.959 & 2.401 & 3.768 & 2.401 & 2.869 \\
\hline 8 & University of Georgia Transit System & GA & 1 & 1 & 1 & 1 & 2.123 & 2.646 & 2.123 & 2.217 \\
\hline 9 & Port Authority Transit Corporation & NJ & 0.691 & 0.758 & 0.691 & 0.757 & 2.120 & 0.697 & 2.120 & 2.150 \\
\hline 10 & Madison County Transit District & $\mathrm{IL}$ & 0.947 & 0.954 & 0.947 & 0.965 & 1.717 & 2.570 & 1.717 & 2.136 \\
\hline 12 & CNY Centro, Inc. & NY & 0.321 & 0.488 & 0.321 & 0.587 & 0.440 & 0.360 & 0.440 & 1.723 \\
\hline 13 & Ride, Inc. - Michigan & MI & 1 & 1 & 1 & 1 & 1.516 & 5.945 & 1.516 & 1.721 \\
\hline 14 & San Francisco Bay Area Rapid Transit District & $\mathrm{CA}$ & 1 & 1 & 1 & 1 & 1.518 & 1.698 & 1.518 & 1.642 \\
\hline 15 & Dallas - Ride, Inc. & TX & 1 & 1 & 1 & 1 & 1.338 & 1.451 & 1.338 & 1.559 \\
\hline 16 & North Front Range Metropolitan Planning Organization & $\mathrm{CO}$ & 0.910 & 1 & 0.910 & 1 & 1.106 & 1.415 & 1.106 & 1.379 \\
\hline 17 & Mountain Metropolitan Transit & $\mathrm{CO}$ & 0.989 & 1 & 0.989 & 1 & 1.270 & 2.135 & 1.270 & 1.325 \\
\hline 18 & Ride, Inc. - Denver & $\mathrm{CO}$ & 0.897 & 1 & 0.897 & 1 & 0.903 & 1.473 & 0.903 & 1.319 \\
\hline 19 & Ride, Inc. - Valley Metro & $\mathrm{AZ}$ & 0.995 & 0.999 & 0.995 & 0.999 & 1.201 & 1.341 & 1.201 & 1.227 \\
\hline 20 & Port Imperial Ferry Corporation dba NY Waterway & NJ & 0.870 & 1 & 0.870 & 1 & 0.858 & 1.192 & 0.858 & 1.177 \\
\hline 21 & BillyBey Ferry Company, LLC & NY & 0.743 & 0.992 & 0.743 & 0.993 & 0.743 & 1.146 & 0.743 & 1.105 \\
\hline 22 & Hudson Transit Lines, Inc. & NJ & 0.786 & 0.973 & 0.786 & 0.979 & 0.847 & 1.086 & 0.847 & 1.084 \\
\hline 23 & Trans-Bridge Lines, Inc. & PA & 0.880 & 1 & 0.880 & 1 & 0.906 & 1.087 & 0.906 & 1.083 \\
\hline 24 & Orange-Newark-Elizabeth, Inc. & $\mathrm{NJ}$ & 0.885 & 1 & 0.885 & 1 & 0.908 & 1.090 & 0.908 & 1.070 \\
\hline
\end{tabular}




\begin{tabular}{|c|c|c|c|c|c|c|c|c|c|c|}
\hline 25 & New Jersey Transit Corporation & NJ & 0.567 & 0.968 & 0.567 & 0.974 & 0.556 & 1.077 & 0.556 & 1.053 \\
\hline 26 & Port Authority Trans-Hudson Corporation & NJ & 0.666 & 0.990 & 0.666 & 0.991 & 0.643 & 1.041 & 0.643 & 1.040 \\
\hline 27 & Lowell Regional Transit Authority & MA & 0.672 & 0.731 & 0.672 & 0.681 & 1.000 & 1.065 & 1.000 & 1.035 \\
\hline 28 & Orange County Transportation Authority & $\mathrm{CA}$ & 0.412 & 0.869 & 0.412 & 0.871 & 0.411 & 1.080 & 0.411 & 1.025 \\
\hline 29 & Chicago Transit Authority & IL & 0.704 & 0.920 & 0.704 & 0.937 & 0.704 & 0.997 & 0.704 & 1.000 \\
\hline 30 & Metropolitan Transit Authority of Harris County, Texas & TX & 0.313 & 0.836 & 0.313 & 0.839 & 0.303 & 1.076 & 0.303 & 0.995 \\
\hline 31 & San Diego Metropolitan Transit System & CA & 0.701 & 0.901 & 0.701 & 0.902 & 0.699 & 1.001 & 0.699 & 0.988 \\
\hline 32 & Academy Lines, Inc. & NJ & 0.764 & 0.935 & 0.764 & 0.944 & 0.764 & 0.977 & 0.764 & 0.977 \\
\hline 33 & Metro-North Commuter Railroad Co. & NY & 0.707 & 0.968 & 0.707 & 0.976 & 0.704 & 0.968 & 0.704 & 0.976 \\
\hline 34 & Massachusetts Bay Transportation Authority & MA & 0.782 & 0.920 & 0.782 & 0.937 & 0.782 & 0.938 & 0.782 & 0.953 \\
\hline 35 & Washington Metropolitan Area Transit Authority & DC & 0.624 & 0.917 & 0.624 & 0.933 & 0.620 & 0.917 & 0.620 & 0.933 \\
\hline 36 & Central Florida Regional Transportation Authority & FL & 0.321 & 0.852 & 0.321 & 0.859 & 0.321 & 0.953 & 0.321 & 0.933 \\
\hline 37 & Los Angeles County Metropolitan Transportation Authority & $\mathrm{CA}$ & 0.532 & 0.853 & 0.532 & 0.882 & 0.503 & 0.882 & 0.503 & 0.902 \\
\hline 38 & Miami Lakes - vRide, Inc. & FL & 0.879 & 0.911 & 0.879 & 0.896 & 0.884 & 0.917 & 0.884 & 0.901 \\
\hline 39 & MTA Long Island Rail Road & NY & 0.649 & 0.854 & 0.649 & 0.887 & 0.581 & 0.854 & 0.581 & 0.887 \\
\hline 40 & VIA Metropolitan Transit & TX & 0.311 & 0.827 & 0.311 & 0.831 & 0.311 & 0.858 & 0.311 & 0.856 \\
\hline 41 & Pace - Suburban Bus Division & IL & 0.233 & 0.829 & 0.233 & 0.838 & 0.233 & 0.847 & 0.233 & 0.852 \\
\hline 42 & King County Depa of Transportation - Metro Transit Division & WA & 0.582 & 0.802 & 0.582 & 0.828 & 0.582 & 0.802 & 0.582 & 0.828 \\
\hline 43 & Monsey New Square Trails Corporation & NY & 0.712 & 0.716 & 0.712 & 0.725 & 0.784 & 0.812 & 0.784 & 0.815 \\
\hline 44 & Utah Transit Authority & UT & 0.331 & 0.796 & 0.331 & 0.809 & 0.331 & 0.796 & 0.331 & 0.809 \\
\hline 45 & Denver Regional Transportation District & $\mathrm{CO}$ & 0.427 & 0.785 & 0.427 & 0.801 & 0.427 & 0.785 & 0.427 & 0.801 \\
\hline 46 & Broward County Transit Division & FL & 0.356 & 0.780 & 0.356 & 0.799 & 0.356 & 0.780 & 0.356 & 0.799 \\
\hline 47 & Metropolitan Atlanta Rapid Transit Authority & GA & 0.503 & 0.782 & 0.503 & 0.792 & 0.503 & 0.782 & 0.503 & 0.792 \\
\hline 48 & Gainesville Regional Transit System & FL & 0.668 & 0.723 & 0.668 & 0.792 & 0.668 & 0.723 & 0.668 & 0.792 \\
\hline 49 & Suburban Transit Corporation & NJ & 0.655 & 0.776 & 0.655 & 0.791 & 0.654 & 0.776 & 0.654 & 0.791 \\
\hline 50 & Board of County Commissioners, PalmTran, Inc. & FL & 0.282 & 0.737 & 0.282 & 0.779 & 0.282 & 0.737 & 0.282 & 0.779 \\
\hline : & $::$ & $:$ & $:$ & & $:$ & & & & & $:$ \\
\hline 295 & Macatawa Area Express Transportation Authority & MI & 0.211 & 0.442 & 0.210 & 0.226 & 0.210 & 0.442 & 0.210 & 0.226 \\
\hline 296 & Shenango Valley Shuttle Service & PA & 0.219 & 0.401 & 0.219 & 0.226 & 0.219 & 0.401 & 0.219 & 0.226 \\
\hline 297 & Housatonic Area Regional Transit & CT & 0.217 & 0.289 & 0.216 & 0.226 & 0.216 & 0.289 & 0.216 & 0.226 \\
\hline 298 & Southeast Area Transit & $\mathrm{CT}$ & 0.213 & 0.279 & 0.213 & 0.224 & 0.212 & 0.279 & 0.212 & 0.224 \\
\hline 299 & Bay Metropolitan Transit Authority & MI & 0.206 & 0.323 & 0.205 & 0.223 & 0.205 & 0.323 & 0.205 & 0.223 \\
\hline 300 & Lakeland Area Mass Transit District & FL & 0.181 & 0.243 & 0.180 & 0.220 & 0.180 & 0.243 & 0.180 & 0.220 \\
\hline 301 & City of Montgomery-Montgomery Area Transit System & $\mathrm{AL}$ & 0.200 & 0.253 & 0.200 & 0.219 & 0.200 & 0.253 & 0.200 & 0.219 \\
\hline 302 & Altoona Metro Transit & PA & 0.203 & 0.397 & 0.202 & 0.219 & 0.202 & 0.397 & 0.202 & 0.219 \\
\hline 303 & Greenville Transit Authority & $\mathrm{SC}$ & 0.203 & 0.259 & 0.202 & 0.218 & 0.202 & 0.259 & 0.202 & 0.218 \\
\hline 304 & Su Tran LLC dba: Sioux Area Metro & SD & 0.198 & 0.280 & 0.197 & 0.217 & 0.197 & 0.280 & 0.197 & 0.217 \\
\hline 305 & The Tri-State Transit Authority & WV & 0.206 & 0.270 & 0.206 & 0.217 & 0.206 & 0.270 & 0.206 & 0.217 \\
\hline 306 & Placer County Department of Public Works & $\mathrm{CA}$ & 0.165 & 0.216 & 0.165 & 0.215 & 0.165 & 0.216 & 0.165 & 0.215 \\
\hline 307 & Butler County Regional Transit Authority & $\mathrm{OH}$ & 0.183 & 0.215 & 0.183 & 0.207 & 0.183 & 0.215 & 0.183 & 0.207 \\
\hline 308 & Clermont Transportation Connection & $\mathrm{OH}$ & 0.194 & 0.304 & 0.194 & 0.206 & 0.194 & 0.304 & 0.194 & 0.206 \\
\hline 309 & County of Lackawanna Transit System & PA & 0.162 & 0.198 & 0.161 & 0.205 & 0.161 & 0.198 & 0.161 & 0.205 \\
\hline 310 & The Greater New Haven Transit District & CT & 0.123 & 0.152 & 0.122 & 0.197 & 0.122 & 0.152 & 0.122 & 0.197 \\
\hline 311 & Concho Valley Transit District & TX & 0.188 & 0.363 & 0.188 & 0.191 & 0.188 & 0.363 & 0.188 & 0.191 \\
\hline 312 & City of Loveland Transit & $\mathrm{CO}$ & 0.142 & 0.643 & 0.142 & 0.188 & 0.142 & .643 & 0.142 & 0.188 \\
\hline 313 & Gary Public Transportation Corporation & IN & 0.179 & 0.314 & 0.179 & 0.185 & 0.179 & 0.314 & 0.179 & 0.185 \\
\hline 314 & Santee Wateree Regional Transportation Authority & $\mathrm{SC}$ & 0.173 & 0.241 & 0.173 & 0.184 & 0.173 & 0.241 & 0.173 & 0.184 \\
\hline 315 & South Lake County Community Services, Inc. & IN & 0.169 & 0.420 & 0.168 & 0.181 & 0.168 & 0.420 & 0.168 & 0.181 \\
\hline 316 & Ulster County Area Transit & NY & 0.171 & 0.259 & 0.171 & 0.177 & 0.171 & 0.259 & 0.171 & 0.177 \\
\hline 317 & Saginaw Transit Authority Regional Service & MI & 0.165 & 0.267 & 0.164 & 0.174 & 0.164 & 0.267 & 0.164 & 0.174 \\
\hline 318 & The Gulf Coast Center & TX & 0.146 & 0.191 & 0.146 & 0.174 & 0.146 & 0.191 & 0.146 & 0.174 \\
\hline 319 & Ozark Regional Transit & AR & 0.143 & 0.190 & 0.143 & 0.168 & 0.143 & 0.190 & 0.143 & 0.168 \\
\hline 320 & Middlesex County Area Transit & NJ & 0.122 & 0.138 & 0.122 & 0.167 & 0.122 & 0.138 & 0.122 & 0.167 \\
\hline 321 & Billings Metropolitan Transit & MT & 0.163 & 0.302 & 0.162 & 0.166 & 0.162 & 0.302 & 0.162 & 0.166 \\
\hline 322 & Handitran Special Transit Division - City of Arlington & TX & 0.133 & 0.198 & 0.133 & 0.157 & 0.133 & 0.198 & 0.133 & 0.157 \\
\hline 323 & City of Jackson Transportation Authority & MI & 0.150 & 0.259 & 0.149 & 0.154 & 0.149 & 0.259 & 0.149 & 0.154 \\
\hline 324 & Dutchess County Division of Mass Transportation & NY & 0.118 & 0.161 & 0.118 & 0.147 & 0.118 & 0.161 & 0.118 & 0.147 \\
\hline 325 & Porter County Aging and Community Services, Inc. & $\mathrm{IN}$ & 0.131 & 0.443 & 0.131 & 0.147 & 0.131 & 0.443 & 0.131 & 0.147 \\
\hline 326 & Council on Aging of St. Lucie, Inc. & FL & 0.122 & 0.190 & 0.121 & 0.142 & 0.121 & 0.190 & 0.121 & 0.142 \\
\hline 327 & City of Riverside Special Transportation & $\mathrm{CA}$ & 0.118 & 0.196 & 0.118 & 0.137 & 0.118 & 0.196 & 0.118 & 0.137 \\
\hline 328 & Medina County Public Transit & $\mathrm{OH}$ & 0.129 & 0.281 & 0.129 & 0.134 & 0.129 & 0.281 & 0.129 & 0.134 \\
\hline 329 & Valley Transit District & CT & 0.117 & 0.466 & 0.117 & 0.131 & 0.116 & 0.466 & 0.116 & 0.131 \\
\hline 330 & Johnson County SEATS & IA & 0.128 & 0.327 & 0.128 & 0.129 & 0.128 & 0.327 & 0.128 & 0.129 \\
\hline 331 & Delaware County Transit Board & $\mathrm{OH}$ & 0.126 & 0.288 & 0.126 & 0.129 & 0.126 & 0.288 & 0.126 & 0.129 \\
\hline 332 & Huntington Area Rapid Transit & NY & 0.101 & 0.221 & 0.101 & 0.108 & 0.101 & 0.221 & 0.101 & 0.108 \\
\hline 333 & City of Glendale Transit & $\mathrm{AZ}$ & 0.100 & 0.206 & 0.100 & 0.107 & 0.100 & 0.206 & 0.100 & 0.107 \\
\hline 334 & Puerto Rico Maritime Transport Authority & PR & 0.070 & 0.074 & 0.070 & 0.093 & 0.070 & 0.074 & 0.070 & 0.093 \\
\hline
\end{tabular}

